DOI 10.18551/rjoas.2021-11.03

\title{
SIMULTANEOUS EFFECT OF INTELLECTUAL CAPITAL AND HEPTAHELIX MANAGERIAL PERFORMANCE ON COMPETITIVE ADVANTAGE: A TNI AL SURVEY IN RIAU ISLANDS
}

\author{
Sidabutar Imam Makmur Saragih*, National Defense Doctoral Student \\ University of Brawijaya, Malang, Indonesia
}

Fadli Mohammad, Nuh Mohammad, Widagdo Setyo, Lecturers

Faculty of National Defense, University of Brawijaya, Malang, Indonesia

*E-mail: imam.makmur1969@gmail.com

\begin{abstract}
The current research was conducted aiming to investigate the simultaneous effect of Intellectual Capital and Heptahelix Managerial Performance on Competitive Advantage. The current research novelty is in the form of measurement of the level of personal performance by combining the Pentahelix and Technology concept as well as the Managerial Performance measurement in the Indonesian Navy (TNI AL), Riau Islands Province, which is called Heptahelix's Managerial Performance. The implication of this research is expected to create superior human resources among the Indonesian Navy in the Riau Islands Province so that they can handle the illegal actions they encounter, since their main tasks and functions is to maintain defense and security in the Marine Territory of the Republic of Indonesia, especially in the Riau Islands Province. This study uses the associative method to see the magnitude of the influence if Intellectual Capital and Heptahelix Managerial Performance are combined together so that later it is hoped that the Navy will excel in competing to maintain the defense and security of the Marine Territory of the Republic of Indonesia, particularly in the Riau Islands Province.
\end{abstract}

\section{KEY WORDS}

Intellectual capital, heptahelix managerial performance, competitive advantage.

As a country which has a total of 17,499 islands and $70 \%$ of the area is ocean, Indonesia is considered as the largest archipelagic country in the world. This Indonesia's status was declared during Djuanda Declaration on 13 December 1957. Furthermore, international recognition concerning the Republic of Indonesia sovereignty as an archipelagic country was approved in the United Nations Convention on the Law of the Sea 1982, which was subsequently ratified through Law Number 17 of $1985 .{ }^{1}$ Indonesia's waters area reaches 5.8 million $\mathrm{km}^{2}$ or equal to $2 / 3$ of its total area. This territorial area consists of 2.7 million $\mathrm{km}^{2}$ Exclusive Economic Zone (EEZ) and 3.1 million $\mathrm{km}^{2}$ territorial waters area (PPPGK, 2016). Therefore, due to its very wide waters area, Indonesia is prone to several criminal acts such as piracy, illegal fishing, illegal mining, terrorism, narcotics trafficking, and environmental pollution, although Indonesia has a lot of potential for abundant marine wealth. This is because Indonesia has very wide marine waters. The Indonesia's waters area is estimated to have stored 6.4 million tons of fish resources per year. However, due to the increased overexploitation and illegal fishing by foreign fishermen, this potential wealth is threatened.

The operation of SDKP (marine fishery resources) surveillance ships has been successfully catching approximately 1,343 fishing vessels for illegal fishing since 2005 . These catches consist of 58 foreign fishing vessels (KIA) and 585 Indonesian fishing vessels (KII). Meanwhile, in $2016^{2}$, KKP has investigated 4,326 fishing vessels, of which 112 fishing vessels consisting of 70 foreign vessels and 42 Indonesian fishing vessels were arrested for conducting violations. Furthermore, based on the data on the capture of fishing vessels in the North Natuna Sea by TNI-AL investigators (LanaiRanai) and the Natuna Regency PSDKP which were delegated to the Natuna District Attorney for trial at the Ranai Fisheries District 
Court, there were 16 foreign vessels entering the Natuna territorial area in 2019, 16 foreign vessels in 2020 and 11 foreign vessels in 2021. Such condition of foreign vessels and unlicensed domestic vessels fishing affects the income of Indonesian traditional fishermen. This is shown from the decrease of the number of Indonesian traditional fishermen from 1.6 million to 864 thousand households $( \pm 50 \%)$ and the decrease in fish production in the Riau Islands region from 2009 (225,469.00 tons) to $133,108.00$ in 2014 (KKP, 2015) as well as economic losses due to illegal fishing which reached IDR 56 Trillion annually. In addition, a seaglider was found on Tenggel Island, Riau Islands in 2019. Yudo Margono (2021) claimed that he found a seaglider that allegedly belonged to China being used for unlicensed oceanographic research (www.cnnindonesia.com). M. Haripin (Military and Defense Observer from LIPI) estimated that this seaglider was employed to find out Indonesia's underwater wealth. In addition, LizzDerr also claimed that Chinese ships have disposed of waste and human waste in the South China Sea for the past 5 (five) years (www.bbc.com). This condition certainly can contaminate the waters around the South China Sea, including the maritime border with Indonesia. In this case, the role of the TNI-AL is needed to guard the Indonesian Sea territory as its main duties implementation which must refer to Article 9 of the Law of the Republic of Indonesia Number 34 of 2004. However, the TNI-AL cannot take a role alone in maintaining the defense and security of the Unitary State of the Republic of Indonesia. In this case, TNI-AL needs to collaborate with other institutions such as BAKAMLA, Ministry of Defense and Security, Ministry of KPP, and assistance from other parties to overcome the problems occur as stated in Law No. 17 of 2011 concerning State Intelligence. ${ }^{3}$ Therefore, other institutions needs to give contribution so that TNI-AL can carry out its main tasks and achieve their personal managerial performance, so that they can reach a competitive advantage, which is also affected by the Intellectual Capital (IC) model.

It is expected that in the future, TNI will have a competitive advantage through IC in maintaining the defense and security of the State, especially in the field of the Navy. Competitive advantage can be achieved when an organization expands or acquires a set of attributes that enable it to perform better than its rival (H.-L. Wang, 2014). Lin (2003) further suggested that technology transfer (TT) can be a significant source of competitive advantage for a company in developing countries with limited R\&D resources. In this case, TT is conceptualized in terms of technology learning performance, organizational intelligence, causal ambiguity, company specificity, complexity, maturity, employee qualifications, and innovation orientation. Managerial performance within the TNI-AL personnel can be achieved by focusing on the Intellectual Capital (IC). With this IC, it is expected that the TNI will have a competitive advantage in the future in order to maintain the defense and security of the Country, especially in the Navy (AL). P. O. de Pablos (2006) added that most of the competitive advantage of transnational organizations lies in their ability to identify and transfer strategic knowledge between their geographically dispersed and diverse locations. Therefore, it can be understood as a sine qua non to achieve a victory (Haffer, 2003). Kay (1993) then argued that the results of competitive advantage are obtained in the form of valuable, rare, non-substitutable, and non-inimitable resources resulting from the integration of special resources and capabilities. Furthermore, concerning competitive advantage with human capital, Bontis et al. (2000) argued that human capital helps to maintain a competitive advantage when employees add value to their unique characteristics. They also claimed that the more unique competencies an individual has in an organization, the more competitive advantage that organization has because rare and valuable employees create more value. Thomas A Steward (1998) further said that a healthy company is a company that has intellectual capital and networks rather than an organizational hierarchy is a good organizational design.

Human capital is an important component (Edvinsson \& Malone, 1997; Sveiby, 1997b; Roos \& Roos, 1997) and a driving force for relational and structural components (Brooking et al., 1998) then added that intellectual capital consists of intangible assets that include markets, intellectual property, infrastructure, and human-centered assets. McElroy's intellectual capital model is based on human capital, structural capital and social capital 
(McElroy, 2002). Ismail further argued that intellectual capital is based on human capital, customer capital, structural capital, and spiritual capital (M. Ismail, 2005). Furthermore, this study also combined the concept of Managerial Performance with the Heptahelix Concept which becomes the novelty of this research as the second study in this topic. The concept of Managerial Performance Heptahelix has never been studied by previous researchers. In addition, the current study employed the Heptahelix concept which is a combination of the Triple-helix Concept (Etzkowitz \& Zhou, 2017); Merchan et al. in (Peris-Ortiz et al., 2016) as cited from (Etzkowitz \& Leydesdorff, 2000), Quadruple Helix Model Concept (Carayannis \& Campbell, 2009), Quintuple-helix (Carayannis \& Campbell, 2009), (Carayannis et al., 2012), Provenzano et al. (2016), (Peris-Ortiz et al., 2016), (Beugré, 2016) and Pentahelix (Muhyi et al., 2017), (Cohen \& Levinthal, 1990) with technology ((Nam \& Pardo, 2011), Al-Hader et al., 2009, (Harrison et al., 2010), (Ihde, 2009); (Verbeek, 2006), (Goeminne \& Paredis, 2011), (Rosenberger \& Verbeek, 2015, 31). Meanwhile, managerial performance is the performance of individual members of the organization according to their respective authorities and responsibilities in managerial positions in order to achieve organizational goals (Lau et al., 1997). Otley (1999) defined performance as something related to the activity of doing work including the work output achieved. Furthermore, Russel Jr. (1984) defined managerial performance as an explicit framework of systematic integration of effort, monitoring, evaluation, finance, and employee performance related to company goals. In this research, managerial performance was measured by adopting eight aspects of personal performance, including planning, investigation, coordination, evaluation, monitoring, supervision, staff management, and representation (Mahoney, 1963).

In addition, diagnostic and interactive MP (Managerial Performance) competencies are considered as important tools in supporting the knowledge capabilities of companies effectively (Lee \& Widener, 2016) in Peters et al. (2016) and for achieving competitive advantage (Simons, 1994 in Peters et al., 2016). Klein (2002) further added that it is not easy to achieve a competitive advantage and there is a relationship between competitive advantage and an organization's performance. The high sustainability of performance can be determined and is closely related to competitive advantage(Powell, 2001). Wide and global empirical literature further contributes on the individual elements of intellectual capital, managerial performance to varied competitive advantage. W.-Y. Wang \& Chang (2005) revealed that all intellectual capital elements directly affect competitive advantage in the information technology industry in Taiwan, except human resources. P. de Pablos (2004) then discovered that among the three elements of intellectual capital, structural capital is the only important element in predicting an organization's competitive advantage in Irish steelworks. In another research, Chen (2008) observed that green intellectual capital positively affects organizational competitive advantage. Ibarra-Cisneros et al., (2020) in their study further discovered that the intangible asset value increases as the tangible assets decrease; this allows organizations, which prioritize intellectual capital to generate competitive advantage. In this case, intellectual capital includes human capital, relational capital and structural capital, of which all of them are not equally significant in affecting the company's competitive position (Bontis, 1998); Stewart, 1997b). Furthermore, Chahal \& Bakshi (2015) found that IC has a direct and positive relationship to competitive advantage with organizational learning as a moderating variable. In this case, (Kamukama et al., 2011) pointed out that the mediating effect of competitive advantage on the relationship between intellectual capital and business performance needs to be further investigated. Kamukama (2013) said their order of importance in explaining the variance in competitive advantage (based on their standard beta values) are structural capital, human capital, and relational capital. Intellectual capital and competitive advantage have produced conflicting results (Tovstiga \& Tulugurova, 2009; J. Barney, 1991; Stewart, 1991). Studies that have been previously done have shown that there is a significant relationship between competitive advantage and performance (Ma, 2000; Fahy, 2000; Ventura \& Giménez Thomsen, 2002; Yonggui \& Hing-Po, 2003; Wiklund \& Shepherd, 2003; Bowen \& Ostroff, 2004; Morgan et al., 2004; Ray et al. (2004). The high sustainability of performance can be determined and is closely related to competitive advantage (Powell, 2001). Regarding the research conducted 
by Kamukama et al (2011) in which they pointed out the need to investigate the mediating effect of competitive advantage on the relationship between intellectual capital and performance, they observed that competitive advantage is achieved by organizations that successfully mobilize their intellectual assets in the form of knowledge, technological skills, experience and strategic capabilities which then lead to better organizational performance. In this case, the high sustainability of performance can be determined and is closely tied to competitive advantage (Powell, 2001).

Based on the definitions provided by several authors, organizational performance can be determined through financial and non-financial performance (Muafi, 2009). In this study, non-financial measures used include organizational effectiveness, efficiency, and adaptation (Homburg et al., 1999), job satisfaction (Harel \& Tzafrir, 1999) and service (Alleyne et al., 2006). Superior organizational performance reflects the company's competitive advantage. Competitive advantage is the ability to win market competition through separate ways that competitors cannot do (Poter, 1998). The results of several previous studies showed that competitive advantage affects organizational performance (Majeed, 2011; Agha et al., 2012; Rose et al., 2010). In this case, competitive advantage can be obtained if the company has the ability to utilize the superior resources, including skills to achieve superior customer value and relatively low costs (Ponter, 1998). The increase of competitive advantage can also be determined based on the age of the company (A. I. Ismail et al., 2010). In this case, the company age actually has an effect on strengthening the competitive advantage owned by the company. Through the research conducted by Rose et al. (2010), they found that the company age is the only factor that can improve the relationship between competitive advantage and organizational performance. This relationship can be achieved in really old companies. Meanwhile, company size does not affect the increase of the relationship between competitive advantage and organizational performance. Competitive advantage is achieved by companies that successfully mobilize their intellectual assets in the form of knowledge, technological skills, experience, and strategic capabilities. (Tovstiga \& Tulugurova, 2009), J. Barney (1991), PRAHALAD CK-HAMEL (1990) in (Kamukama et al., 2011) further claimed that a company's competitive advantage and performance are mostly affected by intellectual capital. Most of the existing literature on IC has ignored the importance of competitive advantage on the relationship between intellectual capital and organizational performance ((Chang \& Lee, 2008; Ho, 2009); (Bonits, 1996); (Stewart, 1997a), (Stewart, 1997b)). In addition to the novelty of Heptahelix's performance employed in the current research, another novelty of this research is in the form of test conducted regarding which competitive advantage can be achieved when uniting and strengthening Intellectual Capital with Heptahelix's Performance. Based on the phenomenon and previous research, this study aimed to determine the Simultaneous Effect of Intellectual Capital and Heptahelix Performance on Competitive Advantage (TNI-AL Survey in Riau Islands)".

\section{LITERATURE REVIEW}

This research was conducted by using three theories; those are Grand Theory, Middle Theory, and Applied Theory. Regarding the theories employed in this research, the Grand Theory employed is the Organization Theory, the Middle Theory employed is Organization Life Cycle Theory, while the Applicated Theory employed is Resource-Based Theory. In this case, the grand theory was adopted from the organization theory proposed by Jones (2001). The knowledge owned by the manager regarding organizational theory creates the ability to analyze the organizational structure and culture, diagnose problems, as well as the ability to adjust the organization's design process that helps the organization to achieve its goals. Correct organizational structure allows every organization to give an effective or responsive response to the environment, technology, or human resources. Furthermore, relevant organizational theory in the current research is the organizational structure theory in which there is complexity in a company which refers to the level of the existing differentiation within an organization. In this case, the differential levels include (Robbins, 1994) horizontal differentiation, vertical differentiation and spatial differentiation. The middle theory applied in 
the current research is the Organization Life Cycle theory which according to Jones (2001), the stages include birth, growth, decline, and death stages. Therefore, it is considered that the Organizational Life Cycles are the stages of an organization starting from birth, growth, maturity, and death. Concerning this definition, Jones further claimed organizational growth as: "the stage of the organizational life cycle in which the organization has the ability is able to develop creation and competence value in order to achieve additional resources. Such growth allows organizations to increase the division of employment and specialization as well as to develop competitive advantages. Based on Life Cycle Stages according to Randolph (1985), the benefits of understanding organizations are "past the decisions of management and the past events in the organization's history has a direct influence on the present and future events and decisions in the organization's life." In this case, the idea of the stages of the organizational life cycle, often associated and recognized comes from the marketing literature on Product Life Cycle (Wright \& Robbins, 1987).

Discussion regarding the idea of Organizational Life Cycles has been carried out for more than 40 years. This can be seen based on the writings of Lippitt \& Schmidt (1967), who claimed that there are three stages of organizational development evolution, those are birth, growth, and maturity. These cycles were then changed to adjust to the developments by Krug \& Oakley (1991), who named it as "phases of reneval stage", and then Jones (2001) proposed it as the Organizational Life Cycles which covers birth, growth, decline, and death stages. According to Greiner (1972), the stages of the organizational life cycle include four stages, those are the birth stage, growth stage, reneval stage, and death stage. Furthermore, in the case of growth stage, there are four stages contained, those are the creativity stage, direction stage, delegation stage, and coordination stages, while in the case of the reneval stage, there are two stages contained, those are maturity stage and decline stage. Greiner (1972) further proposed that there five stages which characterize the organizational evolution/ development. This includes creativity, directing, delegation, coordination, and collaboration. In this case, there is always crisis of each of these stages on the organization. Related to the statement argued by Greiner's previously, there is a possible crisis that might occur in every collaboration. This crisis can be in the forms of the possibility of organizational obsolescence or organizational inertia produced by group think and chronic conflict within the organization that should work together. Group think is a condition in which the collaboration conducted is too close so that it is no longer objective in criticizing the others' opinion, while conflict refers to conflict that occurred between individuals or groups who work together. In order to overcome organizational obsolescence or organizational inertia which is the result of group think and chronic conflict, it requires professional collaboration and openness to continuously learn. Furthermore, the applicated theory employed in the current study is the resource-based theory (RBT). This theory is a further development of Ricardo's Economic Rent theory, and Porter's structure-performance-conduct (J. B. Barney \& Clark, 2007). This theory is proposed from the question raises regarding why a company can outperform other companies and have sustainable superior performance. Companies are able to maintain their advantages if they can build their own resources and have the ability to control them, compared to the companies which buy or obtain resources from outside the organization. In the case of RBT, unique resources referred to resources that are useful/valuable, rare, inimitable, and non-substitutable (J. Barney et al., 2001). Furthermore, Wernerfelt (1984) explained that according to resource-based theory, when companies has the ability to own, control and utilize their important strategic assets (tangible and intangible assets), they will excel in business competition and obtain good financial performance. Riahi-Belkaoui (2003) further stated combining tangible and intangible assets is a potential strategy to improve company performance. Based on the Resource-Based Theory approach, it can be summed up that the company's performance is affected by company's resources which ultimately excel in competition.

\section{METHODS OF RESEARCH}

The current research was implemented through an associative method that 
investigates the effect of the relationship between the variables involved using a theoretical explanation study. This research was further conducted quantitatively, in which this research was conducted by using surveys through questionnaires using an ordinal measurement scale. Furthermore, the population involved in this study was all TNI-AL work units in the districts/cities of the Riau Islands Province. Among the population, samples were collected by using purposive random sampling method in which the sample was taken randomly based on certain criteria determined. These criteria include the samples in Middle Management of TNI-AL, Riau Islands.

\section{RESULTS AND DISCUSSION}

The authors employed the Multiple Linear Regression Method by looking at the value of the Coefficient of Determination in order to answer the hypothesis, which is by testing the relationship between the independent and dependent variables simultaneously. This study employed validity test, reliability test, classical assumption test, as well as the analysis of the coefficient of determination where the samples involved are 100. This test was conducted through the bivariate correlation between each item score and the total item score. The value of the correlation was further compared with the value of $r$ table $\alpha=5 \%$, df $=n-2$, where $n$ indicates the total data used. Therefore, in the case of this research the $n$ used is 100 , then the df value is 98 with a significance level of 0.05 . Furthermore, a reliability test was conducted based on the Cronbach Alpha $>0.60$ from each statement item in the research model (Bougie \& Sekaran, 2016). After the validity and reliability test were fulfilled, then the classical assumption test was performed. Classical Assumption Test includes the test of (1) Normality, (2) Multicolinearity, and (3) Heteroscedasticity. (Ghozali, 2016) claimed that the purpose of conducting the normality test is to investigate whether the confounding or residual variables in the regression model are distributed normally The t-test assumes that the residual value follows a normal distribution, if this assumption is violated, the statistical test becomes invalid for a small sample size. The normality test of the data used by the researcher is the Kolmogorov-Smirnov test with decision making if the significance value is > 0.05 then the data is normally distributed and vice versa. Furthermore, (Ghozali, 2016) claimed that the multicolinearity test aims to test whether the regression model found a correlation between the independent variables because a good regression model should not have a correlation between the independent variables. Multicolinearity test was performed by looking at the tolerance value and Variance Inflation Factor (VIF). Multicolinearity was done by looking at the Tolerance Value and Variance Inflation Factor (VIF) with the criteria Tolerance Value $>0.10$ and Variance Inflation Factor (VIF) $<10$. According to (Ghozali, 2016), one way to detect the presence or absence of heteroscedasticity is to use a Scatter Plot. This test was done by looking at the predictive value of the dependent variable, which is the ZPRED with the residual that is SRESID. If the test results showed no clear pattern, and the points spread above and below the number 0 on the $Y$ axis, it can be considered that there is no heteroscedasticity. Furthermore, the analysis of the coefficient of determination is an analysis that measures the ability of independent variables in explaining the very limited variation of the dependent variable whose purpose is to determine the simultaneous effect of intellectual capital (x1) and heptahelix managerial performance (x2) on competitive advantage $(\mathrm{y})$. The coefficient of determination test equation is as follows: $K d=$ $r^{2} \times 100 \%$. The value of $\mathrm{Kd}$ is never negative and is at most equal to one, thus the formula applied is $0 \leq \mathrm{Kd} \leq 1$. The coefficient of determination is expressed in percent, so the result needs to be multiplied by $100 \%$. The coefficient of determination $\left(\boldsymbol{R}^{2}\right)$ is used to measure how far the model's ability is in explaining the variation of the dependent variable. (Ghozali, 2016: 95) stated that a small $\boldsymbol{R}^{2}$ value means the ability of the independent variables to explain the variation of the dependent variable is very limited. A value close to one means that the independent variables provide almost all the information needed to predict the variation of the dependent variable. The coefficient of determination can show how far the ability of the independent variables simultaneously in contributing or influencing the dependent variable. The $\mathrm{F}$ test basically shows whether all the independent variables used 
have a joint effect on one dependent variable (Ghozali, 2016: 98). The hypothesis that will be tested in this study used the value of $R$ in the ANOVA test. If the significance value of the regression model is simultaneously smaller than the significance level of 0.05 or $5 \%$, i.e. $0.000<0.05$ and the $\boldsymbol{F}_{\text {count }}$ value is greater than $\boldsymbol{F}_{\text {table }}$, then Ha can be accepted, which means that there is a simultaneous influence of the independent variable, namely Intellectual Capital (as variable $\mathrm{x} 1$ ) and Heptahelix Managerial Performance (as variable $\mathrm{x} 2$ ) on Competitive Advantage (as variable y). Purposive random sampling method is a technique of collecting samples by randomly selecting them based on certain criteria, in this case is in Middle Management in the TNI-AL Riau Islands. The analysis was further carried out by calculating the $\mathrm{F}$ value and the Significance Level obtained with the provision that it should not exceed $5 \%$. This can be seen in Figure 1 below:

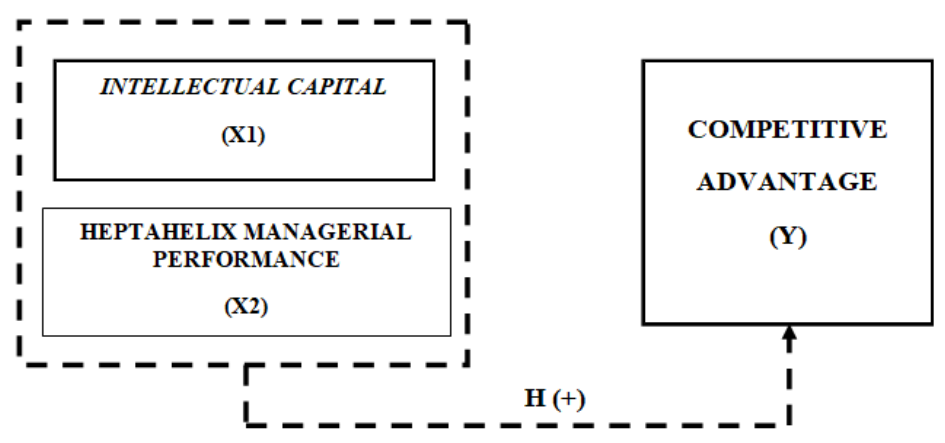

Figure 1 - Simultaneous Effect of Intellectual Capital and Heptahelix Managerial Performance on Competitive Advantage

The implication of this research is expected to be able to answer the problems occurred through the existing hypotheses in this study. The hypotheses in this study were conducted to test the significance of the simultaneous effect between the independent variables and the dependent variable. The independent variables involved are Intellectual Capital (as variable $\mathrm{x} 1$ ) and Managerial Performance Heptahelix (as variable $\mathrm{x} 2$ ), while the dependent variable is competitive advantage (as variable $y$ ) which can be described as follows:

HO: $\beta 1=\beta 2=0$, which indicates that there is no simultaneous effect of independent variables, namely Intellectual Capital (as variable $\mathrm{x} 1$ ) and Heptahelix Managerial Performance (as variable $\mathrm{x} 2$ ) on Competitive Advantage (as variable $\mathrm{y}$ ).

Ha: $\beta 1 \neq \beta 2 \neq 0$, which indicates that there is a simultaneous effect of independent variables, namely Intellectual Capital (as variable $\mathrm{x} 1$ ) and Heptahelix Managerial Performance (as variable $\mathrm{x} 2$ ) on Competitive Advantage (as variable $\mathrm{y}$ ).

Stages conducted in order to perform $\mathrm{F}$ test are as follow:

- Determining the significance level of $\alpha=5 \%$, which means the significance level is $95 \%$ and the analysis error is $5 \%$;

- Calculating F test:

$$
\mathrm{F}_{\text {count }}=\frac{R^{2} / k}{\frac{\left(1-R^{2}\right)}{(n-k-1)}}
$$

Where: $R^{2}$ - Integrated coefficient of determination; $K$ - Number of independent variable; $n$ - Number of samples.

- Criteria of decision making: $\mathrm{H}_{\mathrm{o}}$ is rejected if $F_{\text {count }}>F_{\text {table }}$ with significancy $\alpha=0,05$; $\mathrm{H}_{\mathrm{o}}$ is accepted if $F_{\text {count }}<F_{\text {table }}$ with significancy $\alpha=0,05$.

$F_{\text {table }}$ value is obtained from:

$$
d f=n-k-1
$$

Where: $\mathrm{N}$ - Number of observation; $\mathrm{k}$ - Independent variable. 


\section{CONCLUSION}

Based on the research that has been performed, the following conclusions were obtained:

- It is expected that this research can answer the research objectives that have been explained in the research hypothesis formulated, that there is a simultaneous effect of independent variables, including Intellectual Capital (as variable $x 1$ ) and Heptahelix Managerial Performance (as variable $\mathrm{x} 2$ ) on Competitive Advantage (as variable y, dependent variable);

- In addition, it is also expected that this research will contribute to creating Superior Human Resources through the measurement of Heptahelix Managerial Performance so that TNI-AL personnel has a competitive advantage in carrying out their duties and functions in the field of defense and security in the territorial waters of the Indonesian Waters area, especially in Riau Islands Province;

- Last, it is expected that this research can give input to internal and external organizational changes, in which it is expected that in carrying out their duties and functions, the TNI-A are excel in competing to maintain the defense and security sector in the Indonesian Waters, especially in Riau Islands Province.

It is expected that the suggestions provided by this research can further be implemented by the Government of the Republic of Indonesia in developing Superior Human Resources in order to provide benefits for TNI-AL personnel to be superior in competing to maintain defense and security in the Indonesian Waters, especially in Riau Islands Province.

\section{ACKNOWLEDGEMENTS}

The author would like to thank God Almighty for His love and blessing, so that the author was able to complete this research. Furthermore, I would like to also express my gratitude to University of Brawijaya, The Chair of the Promoter Team and Expert Members of the Promoter Team who have provided knowledge, guidance and direction to the author. I would also like to thank my family who have supported and motivated the author in a state of joy and sorrow. The author would also like to thank the employees and staff of Natuna District Prosecutor's Office who have provided data information related to research writing and also Chief Commander of Ranai Marine Base in Natuna (Danlanal) who have provided input and information to the author.

\section{REFERENCES}

1. Agha, S., Alrubaiee, L., \& Jamhour, M. (2012). Effect of core competence on competitive advantage and organizational performance. International Journal of Business and Management, 7(1), 192-204.

2. Al-Hader, M., Rodzi, A., Sharif, A. R., \& Ahmad, N. (2009). Smart city components architicture. 2009 International Conference on Computational Intelligence, Modelling and Simulation, 93-97.

3. Alleyne, P., Doherty, L., \& Greenidge, D. (2006). Human resource management and performance in the Barbados hotel industry. International Journal of Hospitality Management, 25(4), 623-646.

4. Barney, J. (1991). Firm resources and sustained competitive advantage. Journal of Management, 17(1), 99-120.

5. Barney, J. B., \& Clark, D. N. (2007). Resource-based theory: Creating and sustaining competitive advantage. Oxford University Press on Demand.

6. Barney, J., Wright, M., \& Ketchen Jr, D. J. (2001). The resource-based view of the firm: Ten years after 1991. Journal of Management, 27(6), 625-641.

7. Beugré, C. D. (2016). Building entrepreneurial ecosystems in sub-Saharan Africa: A quintuple helix model. Springer.

8. Bonits, N. (1996). Managing intellectual capital strategically. 
9. Bontis, N. (1998). Intellectual capital: an exploratory study that develops measures and models. Management Decision.

10. Bontis, N., Keow, W. C. C., \& Richardson, S. (2000). Intellectual capital and business performance in Malaysian industries. Journal of Intellectual Capital.

11. Bougie, R., \& Sekaran, U. (2016). Research Methods For Business: A Skill Building 7 ed. Wily.

12. Bowen, D. E., \& Ostroff, C. (2004). Understanding HRM-firm performance linkages: The role of the "strength" of the HRM system. Academy of Management Review, 29(2), 203221.

13. Brooking, A., Board, P., \& Jones, S. (1998). The predictive potential of intellectual capital. International Journal of Technology Management, 16(1-3), 115-125.

14. Carayannis, E. G., Barth, T. D., \& Campbell, D. F. J. (2012). The Quintuple Helix innovation model: global warming as a challenge and driver for innovation. Journal of Innovation and Entrepreneurship, 1(1), 1-12.

15. Carayannis, E. G., \& Campbell, D. F. J. (2009). "Mode 3'and'Quadruple Helix": toward a 21st century fractal innovation ecosystem. International Journal of Technology Management, 46(3-4), 201-234.

16. Chahal, H., \& Bakshi, P. (2015). Examining intellectual capital and competitive advantage relationship: Role of innovation and organizational learning. International Journal of Bank Marketing.

17. Chang, S.-C., \& Lee, M.-S. (2008). The linkage between knowledge accumulation capability and organizational innovation. Journal of Knowledge Management.

18. Chen, Y.-S. (2008). The positive effect of green intellectual capital on competitive advantages of firms. Journal of Business Ethics, 77(3), 271-286.

19. Cohen, W. M., \& Levinthal, D. A. (1990). Absorptive capacity: A new perspective on learning and innovation. Administrative Science Quarterly, 128-152.

20. de Pablos, P. (2004). A guideline for building an intellectual capital statement: the $3 R$ model. International Journal of Learning and Intellectual Capital, 1(1), 3-18.

21. de Pablos, P. O. (2006). Transnational corporations and strategic challenges: An analysis of knowledge flows and competitive advantage. The Learning Organization.

22. Edvinsson, L., \& Malone, M. S. (1997). Intellectual capital: The proven way to establish your company's real value by finding its hidden brainpower. Piatkus.

23. Etzkowitz, H., \& Leydesdorff, L. (2000). The dynamics of innovation: from National Systems and "Mode 2" to a Triple Helix of university--industry--government relations. Research Policy, 29(2), 109-123.

24. Etzkowitz, H., \& Zhou, C. (2017). The triple helix: University--industry--government innovation and entrepreneurship. Routledge.

25. Fahy, J. (2000). The resource-based view of the firm: some stumbling-blocks on the road to understanding sustainable competitive advantage. Journal of European Industrial Training.

26. Ghozali, I. (2016). Multivariate analysis application with IBM SPSS 23 program. Semarang: Diponegoro University Publishing Agency.

27. Goeminne, G., \& Paredis, E. (2011). Opening up the in-between: Inde's postphenomenology and beyond. Foundations of Science, 16(2-3), 101-107.

28. Greiner, L. E. (1972). Evolution and revolution as organizations grow,'Harvard Business Review, July-August.

29. Haffer, R. (2003). Systemy zarządzania jakością w budowaniu przewag konkurencyjnych przedsiębiorstw [Quality management systems in building competitive advantages of companies]. Wydawnictwo Uniwersytetu Mikołaja Kopernika [Publishing House of Nicolaus Copernicus University], Toruń.

30. Harel, G. H., \& Tzafrir, S. S. (1999). The effect of human resource management practices on the perceptions of organizational and market performance of the firm. Human Resource Management: Published in Cooperation with the School of Business Administration, The University of Michigan and in Alliance with the Society of Human Resources Management, 38(3), 185-199. 
31. Harrison, C., Eckman, B., Hamilton, R., Hartswick, P., Kalagnanam, J., Paraszczak, J., \& Williams, P. (2010). Foundations for smarter cities. IBM Journal of Research and Development, 54(4), 1-16.

32. Ho, K. (2009). Insurer-provider networks in the medical care market. American Economic Review, 99(1), 393-430.

33. Homburg, C., Krohmer, H., \& Workman. Jr, J. P. (1999). Strategic consensus and performance: the role of strategy type and market-related dynamism. Strategic Management Journal, 20(4), 339-357.

34. Ibarra-Cisneros, M. A., Hernández-Perlines, F., \& Rodrl'liguez-Garcl'lia, M. (2020). Intellectual capital, organisational performance and competitive advantage. European Journal of International Management, 14(6), 976-998.

35. Ihde, D. (2009). Postphenomenology and technoscience: The Peking university lectures. Suny Press.

36. Ismail, A. I., Rose, R. C., Abdullah, H., \& Uli, J. (2010). The relationship between organisational competitive advantage and performance moderated by the age and size of firms. Asian Academy of Management Journal, 15(2), 157-173.

37. Ismail, M. (2005). The influence of intellectual capital on the performance of Telekom Malaysia. Universiti Teknologi Malaysia Malaysia.

38. Jones, G. R. (2001). Organizational theory: Text and cases. Prentice Hall.

39. Kamukama, N. (2013). Intellectual capital: company's invisible source of competitive advantage. Competitiveness Review: An International Business Journal.

40. Kamukama, N., Ahiauzu, A., \& Ntayi, J. M. (2011). Competitive advantage: mediator of intellectual capital and performance. Journal of Intellectual Capital.

41. Kay, J. (1993). The structure of strategy. Business Strategy Review, 4(2), 17-37.

42. Klein, J. (2002). Beyond competitive advantage. Strategic Change, $11(6), 317$.

43. Krug, D., \& Oakley, E. (1991). Enlightened Leadership. New York, NY: Fireside.

44. Lau, C. M., Low, L. C., \& Eggleton, I. R. (1997). The interactive effect of budget emphasis, participation and task difficulty on managerial performance: a cross-cultural study. Accounting, Auditing $\backslash \&$ Accountability Journal.

45. Lee, M. T., \& Widener, S. K. (2016). The performance effects of using business intelligence systems for exploitation and exploration learning. Journal of Information Systems, 30(3), 1-31.

46. Lin, B.-W. (2003). Technology transfer as technological learning: a source of competitive advantage for firms with limited R\\&D resources. R\\&D Management, 33(3), 327-341.

47. Lippitt, G. L., \& Schmidt, W. H. (1967). Crises in a developing organization. Harvard Business Review.

48. Ma, H. (2000). Competitive advantage and firm performance. Competitiveness Review: An International Business Journal.

49. Mahoney, T. A. (1963). Development of managerial performance: A research approach. South-western Publishing Company.

50. Majeed, S. (2011). The impact of competitive advantage on organizational performance. European Journal of Business and Management, 3(4), 191-196.

51. McElroy, M. W. (2002). Social innovation capital. Journal of Intellectual Capital.

52. Morgan, N. A., Kaleka, A., \& Katsikeas, C. S. (2004). Antecedents of export venture performance: A theoretical model and empirical assessment. Journal of Marketing, 68(1), 90-108.

53. Muafi, M. (2009). The effects of alignment competitive strategy, culture, and role behavior on organizational performance in service firms. International Journal of Organizational Innovation, 2(1).

54. Muhyi, H. A., Chan, A., Sukoco, I., \& Herawaty, T. (2017). The Penta Helix collaboration model in developing centers of flagship industry in Bandung city. Review of Integrative Business and Economics Research, 6(1), 412-417.

55. Nam, T., \& Pardo, T. A. (2011). Conceptualizing smart city with dimensions of technology, people, and institutions. Proceedings of the 12th Annual International Digital Government Research Conference: Digital Government Innovation in Challenging Times, 
282-291.

56. Otley, D. (1999). Performance management: a framework for management control systems research. Management Accounting Research, 10(4), 363-382.

57. Peris-Ortiz, M., Ferreira, J. J., Farinha, L., \& Fernandes, N. O. (2016). Introduction to multiple helix ecosystems for sustainable competitiveness. In Multiple helix ecosystems for sustainable competitiveness (pp. 1-13). Springer.

58. Peters, M. D., Wieder, B., Sutton, S. G., \& Wakefield, J. (2016). Business intelligence systems use in performance measurement capabilities: Implications for enhanced competitive advantage. International Journal of Accounting Information Systems, 21, 117.

59. Ponter, M. E. (1998). Competitive advantage: Creating and sustaining superior performance. Free press.

60. Porter, M. E. (1999). Michael Porter on competition. Antitrust Bull., 44, 841.

61. Powell, T. C. (2001). Competitive advantage: logical and philosophical considerations. Strategic Management Journal, 22(9), 875-888.

62. PRAHALAD CK-HAMEL, G. (1990). The Core Competence of the corporation Harvard Business Review, Vol. 68.

63. Provenzano, V., Arnone, M., \& Seminara, M. R. (2016). Innovation in the rural areas and the linkage with the Quintuple Helix Model. Procedia-Social and Behavioral Sciences, 223, 442-447.

64. Randolph, W. A. (1985). Understanding and managing organizational behavior: A developmental perspective. RD Irwin.

65. Ray, G., Barney, J. B., \& Muhanna, W. A. (2004). Capabilities, business processes, and competitive advantage: choosing the dependent variable in empirical tests of the resource-based view. Strategic Management Journal, 25(1), 23-37.

66. Riahi-Belkaoui, A. (2003). Intellectual capital and firm performance of US multinational firms: A study of the resource-based and stakeholder views. Journal of Intellectual Capital.

67. Robbins, S. P. (1994). Organization theory: structure, design; and Applications.Englewood Cliffs: Prentice.

68. Roos, G., \& Roos, J. (1997). Measuring your company's intellectual performance. Long Range Planning, 30(3), 413-426.

69. Rose, R. C., Abdullah, H., \& Ismad, A. I. (2010). A Review on the Relationship between Organizational Resources, Competitive Advantage and Performance. Journal of International Social Research, 3(11).

70. Rosenberger, R., \& Verbeek, P. P. C. C. (2015). Postphenomenological investigations: essays on human-technology relations. Lexington Books.

71. Russel Jr, R. L. (1984). Performance of a working face recognition machine using cortical thought theory.

72. Simons, R. (1994). Levers of control: How managers use innovative control systems to drive strategic renewal. Harvard Business Press.

73. Stewart, T. A. (1991). Brainpower. Fortune, 123(11), 44.

74. Stewart, T. A. (1997a). A satisfied customer isn't enough. Fortune, 136(2), 112-113.

75. Stewart, T. A. (1997b). Intellectual capital: the new wealth of organizations, Bantam Doubleday Dell Publishing Group. Inc., New York, NY.

76. Sveiby, K. E. (1997a). The intangible assets monitor. Journal of Human Resource Costing $\backslash \&$ Accounting.

77. Sveiby, K. E. (1997b). The new organizational wealth: Managing I\& measuring knowledge-based assets. Berrett-Koehler Publishers.

78. Tovstiga, G., \& Tulugurova, E. (2009). Intellectual capital practices: a four-region comparative study. Journal of Intellectual Capital.

79. Ventura, E., \& Giménez Thomsen, C. (2002). Supply chain management as a competitive advantage in the Spanish grocery sector.

80. Verbeek, P.-P. (2006). Materializing morality: Design ethics and technological mediation. Science, Technology, I\& Human Values, 31(3), 361-380. 
81. Wang, H.-L. (2014). Theories for competitive advantage.

82. Wang, W.-Y., \& Chang, C. (2005). Intellectual capital and performance in causal models: Evidence from the information technology industry in Taiwan. Journal of Intellectual Capital.

83. Wernerfelt, B. (1984). A resource-based view of the firm. Strategic Management Journal, 5(2), 171-180.

84. Wiklund, J., \& Shepherd, D. (2003). Knowledge-based resources, entrepreneurial orientation, and the performance of small and medium-sized businesses. Strategic Management Journal, 24(13), 1307-1314.

85. Wright, P. L., \& Robbins, S. P. (1987). Organization Theory: Readings and Cases. Prentice Hall.

86. Yonggui, W., \& Hing-Po, L. (2003). Customer-focused performance and the dynamic model for competence building and leveraging. A resource-based view. The Journal of Management Development, 22(6), 483-526.

87. PPPGK. (2016). https://mgi.esdm.go.id/content/morfologi-dasar-laut-indonesia. Accessed on March 4th, 2016.

88. KKP. (2015). https://www.conservation-strategy.org/sites/default/files/fieldfile/MFP_Natuna_Bahasa_Optimized.pdf

89. Yudo Margono. (2021). The Indonesian Navy Reveals the Function of the Seaglider, a Missile-like Object on Selayar. https://cnnindonesia.com/nasional/20210104121140-20589162/tni-al-ungkap-fungsi-seaglider-benda-mirip-rudal-di-selayar. Accessed on Jan 4th 2021, 12:27 WIB.

90. Muhammad Haripin. (2021). Seagliders have been found three times in Indonesian waters in the last two years 'evidence of intrusion of sovereignty and lack of detection equipment'. https://www.bbc.com/indonesia/indonesia-55559222. Accessed on Jan 9th 2021. 